\title{
IFRS Adoption in Developing Countries: What Is the Impact?
}

\author{
Chris D. Gingrich (Corresponding author) \\ Eastern Mennonite University \\ 1200 Park Road, Harrisonburg, VA 22802 USA \\ Tel: 540-432-4154 E-mail: chris.gingrich@emu.edu \\ Leah Kratz \\ Eastern Mennonite University \\ 1200 Park Road, Harrisonburg, VA 22802 USA \\ Ryan Faraci \\ Eastern Mennonite University \\ 1200 Park Road, Harrisonburg, VA 22802 USA
}

Received: June 8, 2018

doi:10.5296/ijafr.v8i2.13262
Accepted: June 19, 2018

Published: July 4, 2018

URL: https://doi.org/10.5296/ijafr.v8i2.13262

\begin{abstract}
This study explores the impact of mandatory adoption of the International Financial Reporting Standards (IFRS) in developing countries on business leaders' perceptions of the overall accounting and financial environment. The study employs survey data from the World Economic Forum's Global Competitiveness Report to gauge business leaders' perceptions of the accounting and financial environment. Eight countries across Latin America, Africa, and Asia comprise case studies, all of whom recently adopted mandatory IFRS use for publicly listed companies. Each survey variable is tracked over time, comparing pre and post IFRS adoption, vis-à-vis the same variable in a control country that did not adopt IFRS. IFRS adoption shows mostly positive impacts on the accounting environment in four cases. The impact of adoption in the other three countries is mostly insignificant. These results should
\end{abstract}


encourage policymakers in developing countries to improve auditing and enforcement practices to increase the likelihood of positive results from IFRS adoption.

Keywords: IFRS, World Economic Forum, Developing countries

\section{Introduction}

Increased globalization during the last three decades has prompted many countries to seek internationally standardized rules on financial reporting. To that end, approximately 120 countries currently employ the International Financial Reporting Standards, or IFRS (Mohammadrezaei et al., 2015). This trend reflects a desire to promote cross-national capital flows and greater transparency and comparability of financial statements. While prior studies document the supposed advantages of IFRS adoption, skepticism remains, primarily due to exorbitant implementation costs and a lack of consistent enforcement mechanisms. The latter point carries special concern in developing countries where accounting and auditing institutions are generally weak. While prior studies thoroughly analyze the impact of IFRS adoption, as per local accounting authorities, a void exists in the literature regarding the pros and cons of IFRS adoption in developing countries (Mohammadrezaei et al.).

This study aims to partially fill that void by exploring the effects of mandatory IFRS adoption for publicly listed companies in select developing countries. The study employs a new method by examining business leaders' perceptions of financial reporting quality and access to financial markets after IFRS adoption. In general, the study finds generally positive effects of IFRS adoption, though in select cases there is an indeterminate or negative impact.

The next section briefly surveys the literature on IFRS adoption and its supposed advantages and disadvantages. Section 3 describes the data and methods employed in this study. Section 4 provides the results along with a discussion. Concluding and summary comments complete the paper.

\section{Literature Review/Background}

There is a vast literature covering the pros and cons of mandatory IFRS adoption (De George et al., 2016; Ball, 2006; Mohammadrezaei et al., 2015; Epstein, 2009). Ball (2006) and Epstein (2009) explain that the main argument supporting IFRS adoption is the resulting standardization of reporting across countries. Provided that IFRS implementation is properly enforced - which is suspect in most developing countries - IFRS adoption should also reduce information asymmetries, lower required risk premiums for investors, and reduce capital costs for businesses. Several side effects of mandatory IFRS adoption stem directly from this key assumption.

Horton et al. (2013) examine a cross section of both developed and developing countries to show that IFRS adoption improves the accuracy of earnings forecasts. They argue this result arises from greater comparability of financial reporting. Other evidence of the potential benefits of IFRS adoption in developing countries comes from Mhedhbi and Zeghal (2016), who find a positive correlation between IFRS adoption and firms' price-to-earnings ratios in a sample of 31 developing countries. Ismail (2013) reports higher quality of reported earnings 
in Malaysia (i.e., less earnings manipulation and greater value relevancy) after the country adopted IFRS. Bova and Pereira (2012) find increased share turnover in Kenya following IFRS adoption, presumably arising from greater information transparency. More generally, Ball (2006) explains that standardized reporting prevents companies from "opinion shopping;" that is, choosing an accountant who tailors reports to suit management's interests.

On the other hand, mandatory IFRS adoption also carries potential risks for developing countries. Most obvious is the direct switching cost from existing schemes. One study estimates the continued annual cost of IFRS adoption at approximately 20 percent higher than existing methods (Pawsey, 2017). Khlif and Achek (2016) similarly find that IFRS adoption leads to higher auditing fees. Hope et al. (2006) conclude that countries with less disclosure in reporting are more apt to adopt IFRS, since they have the most to gain from adoption. Given that these countries likely also have the weakest compliance and implementation systems, IFRS adopters potentially generate the worst reporting quality. Ball (2006) similarly explains how the presence of "free riders" (i.e., adopters in name only) dilute the IFRS brand name. Consequently, IFRS adoption creates a false security for investors akin to global metric system adoption with illegitimate measurement methods.

Significant human resource shortages in developing countries can constrain reporting activities and reporting quality. In Ghana, for example, Assenso-Okofo et al. (2011) estimate that 8,000 trained accountants were needed for IFRS adoption while only 3,000 accountants resided in-country. Inusah (2017) confirms similar resource bottlenecks for Ghana that extend to software and regulatory enforcement. In Turkey, IFRS adoption proved disastrous: According to Misirlioğlu et al. (2013), a sample of 106 companies omitted roughly 80 percent of IFRS' required disclosure items when the country first adopted IFRS in 2005. Nurunnabi (2015) reports that both culturally-based corruption and inadequate training of accounting professionals has hampered IFRS implementation in Bangladesh since 1998.

The lack of enforceable auditing standards presents a weak link toward achieving quality IFRS-based reporting. IFRS itself contains no enforcement mechanism (Ball 2006), which is problematic since many IFRS' rules on fair value are open to wide interpretation. Conversely, both dos Santos et al. (2016) and Daske et al. (2008) find that stricter enforcement of IFRS standards produces positive effects such as improved availability of financing and higher quality reporting. Further evidence comes from the International Auditing and Assurance Standards Board (2013), who invited practioners and other stakeholders to review and comment on the International Standards on Auditing (ISA). The summary of reponses noted that "concerns may relate to deficiencies in the ISAs, but could also be the result of auditors not applying the ISAs appropriately for a variety of reasons" (p. 8). Additionally, "...the extent to which the standards are applied consistently within a country depends on the nature and extent of national coordination, including national training provided, and the approach of audit regulators" (p. 9).

\section{Methods/Data Description}

As stated, the goal of the study is to determine how mandatory IFRS reporting affects the perceived accounting environment in developing countries. The literature suggests several 
candidate variables that can proxy the overall accounting environment within a country, including companies' financial statements (Bova and Pereira, 2012; Ismail et al., 2013), stock market performance (Mhedhbi and Zeghal, 2016), and earnings forecasts (Horton et al., 2013). Alternatively, this study examines business leaders' perceptions of the overall accounting environment using survey data. The particular survey data come from the Global Competitiveness Report of the World Economic Forum's (WEF) annual executive survey (WEF 2018b).

The WEF describes its executive survey as follows:

"the Executive Opinion Survey (the Survey) is the longest-running and most extensive survey of its kind, capturing the opinions of business leaders around the world on a broad range of topics for which statistics are unreliable, outdated, or nonexistent for many countries... and provide a more accurate assessment of the business environment...” (p. 333)

WEF surveys are available annually from 2007/08 to 2017/18 (WEF 2018a).

This study is not the first to explore connections between WEF survey results and accounting environments (Boolaky et al., 2013; Boolaky, 2012; Boolaky and Cooper, 2015). These studies rely on cross-national comparisons of survey results using regression models. Unfortunately, such cross-national surveys likely contain bias due to disparate cultural interpretations of survey questions (Kemmelmeier, 2016). Consequently, country A's accounting environment should not be ranked against country B using country-to-country survey comparisons. Instead, this study will examine survey results within a single country for an extended time (11 years). While the WEF surveys may still contain reliability and validity errors, as with any survey, the sampling methods are assumed sufficiently robust as to maximize intra-country validity with minimal sampling bias. (Note 1)

Table 1 describes the specific WEF survey variables this study uses to assess the impact of mandatory IFRS adoption. Variable 1.18 ("Strength of auditing and reporting standards") is an obvious choice since IFRS proponents argue that standardized reporting is key to reducing information asymmetries and strengthening the general accounting environment (Epstein, 2009). Variable 8.03 ("Financing through local equity market") follows directly from variable 1.18 since improved reporting and transparency should reduce risk premiums and capital costs, and motivate domestic investors to include domestic bonds and stocks in their portfolios (Ball, 2006). Variable 8.07 ("Regulation of securities exchanges") is not directly related to IFRS adoption but instead represents a possible government intervention designed to promote well-functioning financial markets. Other related interventions might cover insider trading rules, protection of shareholder rights, and corporate governance regulations. 
Table 1. Survey variables to be examined for the impact of IFRS adoption

\begin{tabular}{lll}
$\begin{array}{l}\text { WEF } \\
\text { Variable }\end{array}$ & Description & Survey question [Likert scale] \\
\hline 1.18 & $\begin{array}{l}\text { Strength of auditing } \\
\text { and reporting } \\
\text { standards }\end{array}$ & $\begin{array}{l}\text { In your country, how strong are financial auditing and } \\
\text { reporting standards? [1 = extremely weak; } 7= \\
\text { extremely strong] }\end{array}$ \\
\hline 8.03 & $\begin{array}{l}\text { Financing through } \\
\text { local equity market }\end{array}$ & $\begin{array}{l}\text { In your country, to what extent can companies raise } \\
\text { money by issuing shares and/or bonds on the capital } \\
\text { market? [1 = not at all; 7 = to a great extent] }\end{array}$ \\
\hline 8.07 & $\begin{array}{l}\text { Regulation } \\
\text { securities exchanges }\end{array}$ & $\begin{array}{l}\text { In your country, to what extent do regulators ensure the } \\
\text { stability of the financial market? [1 = not at all; 7 = to a } \\
\text { great extent] }\end{array}$ \\
\hline
\end{tabular}

Source: WEF (2018b).

The approach used to determine whether mandatory IFRS adoption impacts any of the Table 1 variables is to examine countries that adopted IFRS between 2007/08 and 2017/18 and observe the status of each variable. Because of potential cultural bias, the actual response level is irrelevant. Rather, the key result is any intertemporal change arising from IFRS implementation. With sufficiently large sample sizes the preferred analytical methods for this task would be either an interrupted time series model (Lagarde, 2012) or an ARIMA model (Enders, 2009). However, the maximum available sample size here is 11, which is inadequate for either application. In lieu of these models, this study compares mean values for each WEF variable in IFRS adopting countries before and after the specific adoption date. In the hypothetical ceteris paribus case, with no macroeconomic shocks or non-IFRS policy changes, this technique would be appropriate. In reality, however, there is the counterfactual question: How might the specific variable have changed in the absence of IFRS adoption?

Thus, to approximate a "control" country for the IFRS-adopting "treatment" country, this study compares intertemporal changes in each WEF variable in adopting countries to the same variable in a neighboring nonadopting country. The underlying logic is that regional macroeconomic events should similarly affect survey variables across countries. Hence, the test for any IFRS-related impact is then whether the mean difference in each WEF variable (IFRS country minus non-IFRS country) significantly changes after IFRS adoption.

To illustrate, consider Figure 1, which shows variable 8.03 for Ecuador, an IFRS adopter in 2010, and Colombia, a non-IFRS control country. During Ecuador's pre-IFRS period (2007/08 to 2009/10), variable 8.03 for Colombia exceeded Ecuador (mean $=-1.08$ ). Following Ecuador's adoption of IFRS in 2010, the gap between the countries steadily narrowed (mean = $-0.38)$. Because these two mean values are significantly different $(p=0.08)$, IFRS improved access to financing in Ecuador's equity market. 


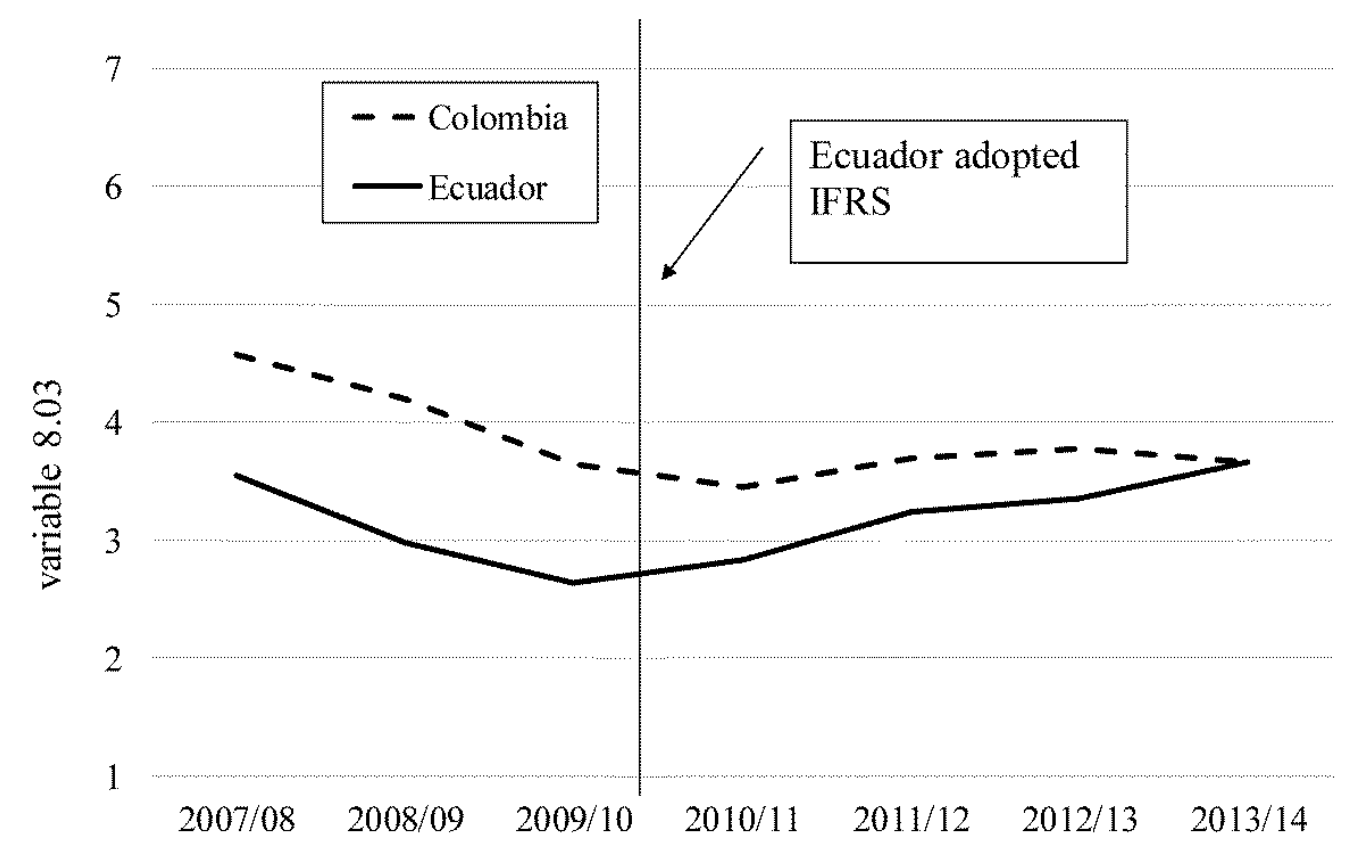

Figure 1. Variable 8.03 for Ecuador and Colombia, 2007/08 to 2013/14

Figure 1 also illustrates the perils of analyzing a country's survey variables in isolation. Between 2007/08 and 2009/10, variable 8.03 ("Financing through local equity market") for both countries sharply declined, presumably due to the global recession. In isolation, it thus falsely appears that Ecuador implemented a major policy change from 2007 to 2010 that disrupted its financial markets. In reality, both countries' financial markets contracted during the global recession, but Ecuador began to improve relative to Colombia starting in 2010/11.

Unfortunately, the list of candidate countries available to apply the above methods is quite limited. First, only counties from the World Bank's list of low and middle income countries are considered (World Bank, 2018). Second, countries that experienced extreme disasters or war between 2007 and 2018 (e.g., Haiti, Syria, Yemen) are omitted. Third, IFRS-adopting countries must have begun to fully require IFRS for publicly listed companies between 2010 and 2014. Both earlier and later adopters, even within the 2007-2018 window, are omitted since the resulting sample sizes for either pre- or post-IFRS mean calculations would be inadequate. Fourth, IFRS-adopting countries must have an active stock exchange, or participate in a regional stock exchange. Fifth, each IFRS-adopting country must have a neighboring nonadopting country with a similar culture, income level and an active stock exchange that can serve as an effective control. This list includes countries that permit IFRS, though do not require it for publicly listed companies. When there is more than one choice for the control country, the country with the highest correlation for variable 1.18 during the pre IFRS period is used. Table 2 describes the eight IFRS-adopting countries, and their accompanying control countries. 
Table 2. List of IFRS adopter and corresponding nonadopter countries

\begin{tabular}{lll}
\hline Region/Country & $\begin{array}{l}\text { IFRS Status : } \\
\text { A=adopter (when } \\
\text { adopted), N=nonadopter }\end{array}$ & Notes \\
\hline Nigeria & A (Jan. 1, 2012) & \\
\hline Benin & $\mathrm{N}$ & $\begin{array}{l}\text { Cameroon also a viable comparison to Nigeria } \\
\text { but Benin has a higher pre-IFRS correlation } \\
\text { coefficient for variable } 1.18(0.74 \text { vs. }-0.62) ; \\
\text { member of BRVM regional stock exchange } \% \\
\text { WEF data not available 2014/15 }\end{array}$ \\
\hline
\end{tabular}

\begin{tabular}{lll}
\hline $\begin{array}{l}\text { Kyrgyz } \\
\text { Republic }\end{array}$ & A (Feb. 2013) & IFRS adoption source: https://www.ifac.org \\
\hline Pakistan & N & $\begin{array}{l}\text { While IFRS required for public companies (as } \\
\text { of 2015), some key standards omitted }\end{array}$ \\
\hline Sri Lanka & A (Jan. 1, 2012) & \\
\hline Indonesia & N & IFRS not permitted for public companies \\
\hline
\end{tabular}

\begin{tabular}{lll}
\hline Cambodia & A (Jan. 1, 2012) & \\
\hline Myanmar & N & $\begin{array}{l}\text { Adopted IFRS in 2010, but no active stock } \\
\text { exchange until Dec 2015; } \\
\text { Data only used through 2015 }\end{array}$ \\
\hline Malaysia & A (Jan. 1, 2012) & $\begin{array}{l}\text { According to Ismail (2013) IFRS adopted on } \\
\text { Jan. 1, 2006 }\end{array}$ \\
\hline Indonesia & N & IFRS not permitted for public companies \\
\hline Peru & A (Jan. 1, 2012) & $\begin{array}{l}\text { WEF data not available 2017/18; } \\
\text { Public companies must follow local standards, } \\
\text { not IFRS }\end{array}$ \\
\hline Bolivia & N & \\
\hline Ecuador & A (Jan. 1, 2010) & WEF data not available 2014/15 \\
\hline
\end{tabular}


Fully adopted IFRS for public firms on Jan. 1,

2015;

Data only used through 2013/14

\begin{tabular}{lll}
\hline El Salvador & A (2011) & \\
\hline Guatemala & $\mathrm{N}$ & IFRS permitted but not required; \\
& & $\begin{array}{l}\text { Guatemala used in lieu of Honduras since there } \\
\text { is no functioning stock market in Honduras }\end{array}$ \\
\hline
\end{tabular}

*Source: http://www.IFRS.org/use-around-the-world/use-of-IFRS-standards-by-jurisdiction/

Source: https://www.ifac.org/about-ifac/membership/country/

${ }^{\%}$ BRVM: Bourse Régionale des Valeurs Mobilières (http://www.brvm.org/en)

thttp://www.IFRS.org/use-around-the-world/use-of-IFRS-standards-by-jurisdiction/honduras/

The emphasis on IFRS use for public companies stems from an assumption that the effects of mandatory IFRS adoption for public companies will quickly spread throughout the business community, including to privately held companies. This assumption is logical for countries with well-established, high-volume stock exchanges, though some countries in Table 1 have stock exchanges that are either new and/or low-volume. (Note 2)

One minor problem involved confirming the IFRS adoption status of several countries. For the vast majority of cases, the official IFRS website (IFRS.org), the International Federation of Accountants (ifac.org), and independent research papers all agreed on the IFRS adoption status and adoption timing. However, any conflicts were resolved using the IFRS website as the final authority.

Returning to possible survey bias, Soto-Rodriguez and Maíz-Vázquez (2016) argue that WEF surveys do not reflect broad attitudes on social issues since they are drawn exclusively from upper-level management and other business leaders and therefore contain "hierarchical bias." Such bias likely exists for survey variables such as "Public trust in politicians" (variable 1.04) and "Reliability of police services" (variable 1.16). However, hierarchical bias is less problematic for accounting-related variables since executives and business leaders should be more attuned to the accounting and reporting environment than the general public.

\section{Results}

Mandatory IFRS adoption appears to generally improve the financial reporting environment in the eight observed countries, though the result is not uniform (Tables 3 and 4). Specifically, perceived auditing and reporting standards (variable 1.18) improve following IFRS adoption in three countries. However, they also worsen in three countries and show no significant change in two others. Equity market financing and regulation of financial markets improves (four countries for both variables) or does not change following IFRS adoption, except for one negative case. 


\section{1) Macrothink}

International Journal of Accounting and Financial Reporting

ISSN 2162-3082

2018, Vol. 8, No. 2

Table 3. Summary results for WEF survey variables, pre versus post IFRS adoption

\begin{tabular}{|c|c|c|c|c|}
\hline $\begin{array}{l}\text { IFRS adopting } \\
\text { country (control } \\
\text { country) }\end{array}$ & $\begin{array}{l}\text { WEF } \\
\text { variable; } \\
\mathrm{N}=\text { sample } \\
\text { size }\end{array}$ & $\begin{array}{l}\text { pre-IFRS mean } \\
\text { (compared to } \\
\text { control country) }\end{array}$ & $\begin{array}{l}\text { post-IFRS mean } \\
\text { (compared to } \\
\text { control country) }\end{array}$ & $\begin{array}{l}\mathrm{p} \text { value for null } \\
\text { hypothesis of equal } \\
\text { means (pre and post } \\
\text { IFRS) }\end{array}$ \\
\hline \multirow[t]{4}{*}{ Nigeria (Benin) } & 1.18 & 0.248 & 0.841 & 0.03 \\
\hline & 8.03 & 1.177 & 0.771 & 0.36 \\
\hline & 8.07 & 0.586 & 1.106 & 0.25 \\
\hline & $\mathrm{N}$ & 5 & 5 & \\
\hline \multirow{4}{*}{$\begin{array}{l}\text { Kyrgyz Republic } \\
\text { (Pakistan) }\end{array}$} & 1.18 & -0.940 & -0.301 & 0.01 \\
\hline & 8.03 & -1.622 & -0.944 & $<0.01$ \\
\hline & 8.07 & -1.444 & -0.958 & 0.12 \\
\hline & $\mathrm{N}$ & 6 & 5 & \\
\hline \multirow{4}{*}{$\begin{array}{l}\text { Sri Lanka } \\
\text { (Indonesia) }\end{array}$} & 1.18 & 0.665 & 0.425 & 0.05 \\
\hline & 8.03 & -0.133 & 0.437 & 0.11 \\
\hline & 8.07 & 0.116 & 0.122 & 0.98 \\
\hline & $\mathrm{N}$ & 5 & 6 & \\
\hline \multirow{4}{*}{$\begin{array}{l}\text { Cambodia } \\
\text { (Myanmar) }\end{array}$} & 1.18 & -0.918 & -0.713 & 0.33 \\
\hline & 8.03 & -2.820 & -1.790 & 0.06 \\
\hline & 8.07 & -1.93 & -1.01 & 0.05 \\
\hline & $\mathrm{N}$ & 5 & 3 & \\
\hline \multirow{4}{*}{$\begin{array}{l}\text { Malaysia } \\
\text { (Indonesia) }\end{array}$} & 1.18 & 0.950 & 0.980 & 0.83 \\
\hline & 8.03 & 0.033 & 0.563 & 0.02 \\
\hline & 8.07 & 0.377 & 0.883 & 0.06 \\
\hline & $\mathrm{N}$ & 5 & 6 & \\
\hline Peru (Bolivia) & 1.18 & 1.402 & 0.968 & 0.08 \\
\hline
\end{tabular}




\begin{tabular}{lllll}
\hline & 8.03 & 1.161 & 0.337 & 0.02 \\
\hline & 8.07 & 0.370 & 0.559 & 0.07 \\
\hline & $\mathrm{N}$ & 5 & 5 & \\
\hline $\begin{array}{l}\text { Ecuador } \\
\text { (Colombia) }\end{array}$ & 1.18 & -0.613 & -0.298 & 0.08 \\
\hline & 8.03 & -1.077 & -0.378 & 0.01 \\
\hline & 8.07 & -0.610 & 0.314 & 0.08 \\
\hline & $\mathrm{N}$ & 3 & 4 & $<0.01$ \\
\hline $\begin{array}{l}\text { El Salvador } \\
\text { (Guatemala) }\end{array}$ & 1.18 & 0.318 & -0.617 & 0.47 \\
\hline & 8.03 & 0.770 & 0.639 & 0.22 \\
\hline & 8.07 & -0.076 & -0.568 & 7 \\
\hline
\end{tabular}

Source: Author calculations from WEF survey data.

Dark shade indicates a significant (90\% confidence or higher) positive change post IFRS adoption. Light shade indicates a significant negative change post IFRS adoption.

${ }^{+}$Comparison country and years covered described in Table 2.

^See Table 1 for details.

Table 4. Summary of IFRS adoption results for eight different developing countries

\begin{tabular}{lccc} 
WEF Variable & $\begin{array}{l}\text { Significantly positive } \\
\text { change post-IFRS }\end{array}$ & $\begin{array}{l}\text { Significantly } \\
\text { negative } \\
\text { change } \\
\text { post-IFRS }\end{array}$ & $\begin{array}{l}\text { Post-IFRS change } \\
\text { not significant }\end{array}$ \\
\hline $\begin{array}{l}1.18 \text { (Strength of auditing } \\
\text { and reporting standards) }\end{array}$ & 3 & 3 & 2 \\
\hline $\begin{array}{l}8.03 \text { (Financing through } \\
\text { local equity market) }\end{array}$ & 4 & 1 & 4 \\
\hline $\begin{array}{l}8.07 \text { (Regulation of } \\
\text { securities exchanges) }\end{array}$ & 4 & 0 & \\
\hline
\end{tabular}

Source: Compiled from Table 3. 
Several trends emerge from Tables 3 and 4. Auditing and reporting standards, variable 1.18, show a mixed response to mandatory IFRS adoption. The other two variables show an overall positive impact of IFRS adoption in half the counties and essentially no impact in the other half. Furthermore, lowering the required confidence level to 85 percent due to small sample sizes reveals two more positive results (Sri Lanka for variable 8.03 and Kyrgyz Republic for variable 8.07) and no new negative ones. Only Peru shows a negative change for equity market financing. Especially noteworthy is that four countries show positive effects of IFRS adoption for multiple variables (Ecuador, Malaysia, Cambodia, and Kyrgyz Republic).

Since critics claim that IFRS adoption carries potential advantages and disadvantages depending on the cultural, financial, and regulatory environment (Ball, 2006; Pawsey, 2017; Mohammadrezaei et al., 2015), so it is not surprising that the observed effects are also mixed. From the available data, the reasons why IFRS adoption quickly improved the reporting environment in roughly half the observed countries remains unknown. One factor could be the specific survey question used to assess accounting standards. Table 1 describes the survey question for variable 1.18: "In your country, how strong are financial auditing [italics added] and reporting standards?" Ideally, this question should have been split in two, rather than combining auditing and reporting queries. Hence, the end user cannot know which term, auditing or reporting, was forefront for survey respondents. Where questionable auditing practices prevailed during IFRS adoption, as in Peru, El Salvador, and Sri Lanka (IFAC, 2018), it is hard to imagine favorable responses to questions that include the word "auditing."

Moreover, detailed auditing practices are difficult to know in each country. While the most thorough auditing information is available from the World Bank, these reports are outdated for most countries (e.g., World Bank, 2004). The only possible conclusion is that heterogeneous auditing practices likely influenced the survey results for variable 1.18 in all eight countries.

Somewhat surprisingly, the question of short versus long run effects of IFRS adoption has received scant attention in the literature. Nonetheless, it is plausible that a "J-curve" effect exists in some settings, where lax enforcement, human resource shortages, and high startup costs cause the reporting environment to initially deteriorate following mandatory IFRS adoption. These market disequilibria, such as a shortage of trained accountants and auditors, should dissipate over time and begin yielding possible benefits from IFRS adoption. Whether this process requires two or ten years remains unclear, but it is safe to assume that imperfect labor markets in developing countries contribute to such lags (Cho et al., 2012).

Arguably the main reason for a negative or indeterminate impact of IFRS adoption stems from weak auditing practices. Ball (2006) and Epstein (2009) describe how accounting standards must be supported by legitimate and independent audits. Unfortunately, auditing practices in many developing countries are "toothless," according to Ball. In fact, one interpretation is that, because all the observed countries likely have weak auditing systems and practices, it is surprising that half the countries show positive effects of IFRS adoption.

Because IFRS requires significant judgement calls, IFRS-based reporting can vary significantly across countries. Some of these judgements are rooted in cultural differences. 


\section{М Macrothink}

International Journal of Accounting and Financial Reporting

ISSN 2162-3082

2018, Vol. 8, No. 2

Tsakumis et al. (2009) explain how cultures with high uncertainty avoidance and low individualism and achievement orientation show increased conservatism in reporting (i.e., recognition of income-generating assets). Similarly, high reporting secrecy (i.e., restricting information from outside parties) stems from greater cultural emphasis on uncertainty avoidance and power distance and less emphasis on individualism and achievement orientation. The authors further describe how even the translation of IFRS from its original English to the relevant host language can yield ambiguous reporting rules.

While the specific reasons for disparate results from mandatory IFRS adoption in developing countries are unknown, the effects are generally positive, even in the very short run. Moreover, those individuals making this assessment are business executives and leaders, or the end users and producers of the reporting information. Thus, while IFRS adoption can raise switching and compliance costs (Khlif and Achek, 2016), these findings indicate potentially offsetting benefits. Some of these benefits occur as positive externalities and suggest government subsidies for IFRS adoption.

Developing countries that have recently adopted IFRS should not waiver with their decision. In addition, Mohammadrezaei et al. (2015) explain how some countries are still waiting for empirical proof of IFRS' benefits before proceeding with adoption. This evidence should provide further encouragement for adoption. However, to raise the probability of tangible benefits, policymakers must also address human capital shortages and weak auditing systems.

Somewhat surprising is that the country with the smallest and newest stock exchange, Cambodia, still shows countrywide benefits of IFRS adoption. This result suggests that IFRS adoption for public firms generates positive signals to the broader business community.

\section{Conclusion}

This study finds mostly positive effects of IFRS adoption for three accounting-related survey variables in eight different developing countries. The variables reflect business leaders and executives' perceptions of the financial reporting environment in each country. The findings are not uniform, however, and in a few cases are indeterminate or negative.

While the precise reasons for the disparate results lie beyond this study's scope, the most likely culprits are heterogeneous enforcement mechanisms and cultural influences on financial statement preparation. There is insufficient evidence to advise IFRS-in-waiting countries to postpone adoption plans or to rollback existing adoption schemes. Consistent with existing literature, this study advises tightening auditing and enforcement mechanisms to help disseminate IFRS benefits more broadly.

\section{References}

Assenso-Okofo, O., Ali, M. J., \& Ahmed, K. (2011). The development of accounting and reporting in Ghana. The International Journal of Accounting, 46(4), 459-480. https://doi.org/10.1016/j.intacc.2011.09.010

Ball, R. (2006). International Financial Reporting Standards (IFRS): Pros and cons for investors. Accounting and Business Research, 36, 5-27. 
https://doi.org/10.1080/00014788.2006.9730040

Boolaky, P. K. (2012). Auditing and reporting in Europe: An analysis using country-level data. Managerial Auditing Journal, 27(1), 41-65. https://doi.org/10.1108/02686901211186090

Boolaky, P. K., \& Cooper, B. J. (2015). Comparing the strength of auditing and reporting standards and investigating their predictors in Europe and Asia. Australian Accounting Review, 25(3), 292-308. https://doi.org/10.1111/auar.12058

Boolaky, P. K., Krishnamurti, C., \& Hoque, A. (2013). Determinants of the strength of auditing and reporting standards: A cross-country study. Australasian Accounting, Business and Finance Journal, 7(4), 17-36. https://doi.org/10.14453/aabfj.v7i4.3

Bova, F., \& Pereira, R. (2012). The determinants and consequences of heterogeneous IFRS compliance levels following mandatory IFRS adoption: Evidence from a developing country. Journal of International Accounting Research, 11(1), 83-111. https://doi.org/10.2308/jiar-10211

Cho, Y., Margolis, D., Newhouse, D., \& Robalino, D. (2012). Labor markets in low- and middle-income countries trends and implications for social protection and labor policies. World Bank Discussion Paper No. 1207. Retrieved April 27, 2018, from http://siteresources.worldbank.org/socialprotection/Resources/SP-Discussion-papers/LaborMarket-DP/1207.pdf

Daske, H., Hail, L., Leuz, C., \& Verdi, R. (2008). Mandatory IFRS reporting around the world: Early evidence on the economic consequences. Journal of Accounting Research, 46(5), 1085-1142. https://doi.org/10.1111/j.1475-679X.2008.00306.x

De George, E. T., Li, X., \& Shivakumar, L. (2016). A review of the IFRS adoption literature. Review of Accounting Studies, 21(3), 898-1004. https://doi.org/10.1007/s11142-016-9363-1

dos Santos, M. A., Fávero, L. P. L., \& Distadio, L. F. (2016). Adoption of the International Financial Reporting Standards (IFRS) on companies' financing structure in emerging economies. Finance Research Letters, 16, 179-189. https://doi.org/10.1016/j.frl.2015.11.002

Enders, W. (2009). Applied econometric time series. New York: Wiley.

Epstein, B. J. (2009). The economic effects of IFRS adoption. CPA Journal, 79(3), 26-31.

Hope, O., Jin, J., \& Kang, T. (2006). Empirical evidence on jurisdictions that adopt IFRS. Journal of International Accounting Research, 5(2), 1-20. https://doi.org/10.2308/jiar.2006.5.2.1

Horton, J., Serafeim, G., \& Serafeim, I. (2013). Does mandatory IFRS adoption improve the information environment? Contemporary Accounting Research, 30(1), 388-423. https://doi.org/10.1111/j.1911-3846.2012.01159.x

International Auditing and Assurance Standards Board (IAASB). (2013). Clarified international standards on auditing-findings from the post-implementation review. Retrieved 
May

15 ,

2018 ,

from

https://www.ifac.org/publications-resources/clarified-isas-findings-post-implementation-revie $\mathrm{W}$

International Federation of Accountants (IFAC). (2018). Member organizations and country profiles. $\quad$ Retrieved April 6, 2018, from https://www.ifac.org/about-ifac/membership/member-organizations-and-country-profiles

Inusah, N. (2017). IFRS adoption in Ghana: The dimensions of challenges firms encounter. International Journal of Accounting and Financial Reporting, 7(2), 194-209. https://doi.org/10.5296/ijafr.v7i2.12028

Ismail, W. A. W., Kamarudin, K. A., van Zijl, T., \& Dunstan, K. (2013). Earnings quality and the adoption of IFRS-based accounting standards: Evidence from an emerging market. Asian Review of Accounting, 21(1), 53-73. https://doi.org/10.1108/13217341311316940

Kemmelmeier, M. (2016). Cultural differences in survey responding: Issues and insights in the study of response biases. International Journal of Psychology, 51(6), 439-444. https://doi.org/10.1002/ijop.12386

Khlif, H., \& Achek, I. (2016). IFRS adoption and auditing: A review. Asian Review of Accounting, 24(3), 338-361. https://doi.org/10.1108/ARA-12-2014-0126

Lagarde, M. (2012). How to do (or not to do) ... assessing the impact of a policy change with routine longitudinal data. Health Policy and Planning, 27(1), 76-83. https://doi.org/10.1093/heapol/czr004

Mhedhbi, K., \& Zeghal, D. (2016). Adoption of international accounting standards and performance of emerging capital markets. Review of Accounting and Finance, 15(2), 252-272. https://doi.org/10.1108/RAF-08-2013-0099

Misırlığlu, İ. U., Tucker, J., \& Yükseltürk, O. (2013). Does mandatory adoption of IFRS guarantee compliance? International Journal of Accounting, 48(3), 327-363. http://dx.doi.org/10.1016/j.intacc.2013.07.002

Mohammadrezaei, F., Mohd-Saleh, N., \& Banimahd, B. (2015). The effects of mandatory IFRS adoption: A review of evidence based on accounting standard setting criteria. International Journal of Disclosure and Governance, 12(1), 29-77. https://doi.org/10.1057/jdg.2013.32

Nurunnabi, M. (2015). The impact of cultural factors on the implementation of global accounting standards (IFRS) in a developing country. Advances in Accounting, 31, 136-149. http://dx.doi.org/10.1016/j.adiac.2015.03.015

Pawsey, N. L. (2017). IFRS adoption: A costly change that keeps on costing. Accounting Forum, 41(2), 116-131. https://doi.org/10.1016/j.accfor.2017.02.002

Soto-Rodríguez, E., \& Maíz-Vázquez, E. (2016). Implications of including non-executives' perception in the executive opinion survey: A hierarchical bias effect in the global 


\section{Macrothink \\ International Journal of Accounting and Financial Reporting \\ ISSN 2162-3082 \\ 2018, Vol. 8, No. 2}

competitive index. American Journal of Management, 16(3), 82-95.

Tsakumis, G. T., Campbell Sr, D. R., \& Doupnik, T. S. (2009). IFRS: Beyond the standards. Journal of Accountancy, 207(2), 34-39.

World Bank. (2004). Peru - Report on the observance of standards and codes (ROSC): Accounting and auditing (English). Retrieved April 27, 2018, from http://documents.worldbank.org/curated/en/771801468298456358/Peru-Report-on-the-observ ance-of-standards-and-codes-ROSC-accounting-and-auditing

World Bank. (2018). World Bank country and lending groups. Retrieved March 21, 2018, from

https://datahelpdesk.worldbank.org/knowledgebase/articles/906519-world-bank-country-andlending-groups

World Economic Forum (WEF). (2018a). The global competitiveness report 2017-2018 (dataset). $\quad$ Retrieved $\quad$ March 21, 2018, from http://www3.weforum.org/docs/GCR2017-2018/GCI_Dataset_2007-2017.xlsx

World Economic Forum (WEF). (2018b). The global competitiveness report 2017-2018. Retrieved April 27, from http://www3.weforum.org/docs/GCR2017-2018/05FullReport/TheGlobalCompetitivenessRe port2017\%E2\%80\%932018.pdf

\section{Notes}

Note 1. See WEF (2018b, p. 333) for details regarding sample sizes and in-country partners used to facilitate survey collection.

Note 2. For example, the Cambodia Securities Exchange has only five companies (see http://csx.com.kh/data/lstcom/listPosts.do?MNCD=5010).

\section{Copyright Disclaimer}

Copyright for this article is retained by the author(s), with first publication rights granted to the journal.

This is an open-access article distributed under the terms and conditions of the Creative Commons Attribution license (http://creativecommons.org/licenses/by/4.0/) 